\title{
ANALISIS KARAKTERISTIK VECTOR ART PADA VECTORINA MEDAN COMMUNITY TAHUN 2019 DITINJAU DARI ELEMEN VISUAL
}

\author{
Lulu Riskiah Harahap ${ }^{1^{*}}$, Agus Priyatno ${ }^{2 *}$, Osberth Sinaga ${ }^{3 *}$ Onggal Sihite ${ }^{4 *}$
}

\author{
Program Studi Pendidikan Seni Rupa Jurusan Seni Rupa Fakultas Bahasa dan Seni \\ Universitas Negeri Medan \\ Jl. Willem Iskandar Pasar V Medan Estate, Kec, Percut Sei Tuan, Kab. Deli Serdang, Kode Pos 20371 \\ Sumatera Utara. Indonesia \\ Email: luluriskiah01@gmail.com
}

\begin{abstract}
Abstrak
Penelitian inibertujuan untuk mengetahui karakteris tik elemen-elemen visual yang terdiri dari garis, warna dan gelap terang pada karya vector art di Vectorina Medan Community tahun 2019. Adapun populasi yang terdapat dalam penelitian ini sebanyak 15 karya vector art di Vectorina Medan Community sehingga sampel yang ditetapkan dalam penelitian ini terdiri dari 3 karya dengan menggunakan teknik Purposive Sampling. Penelitian ini menggunakan metode kualitatif deskriptif untuk mengetahui dan mendeskripsikan kekuatan karakteristik vector art di Vectorina Medan Community yang dijadikan s ampel berdasarkan karakteristik dari garis, warna dan gelap terang. Hasil penelitian menunjukkan, kekuatan elemen-elemen vis ual berdasarkan karakteristik adalah berasal dari penggambaran dan penentuan elemen-elemen visual yang baik seperti penempatan warna, gelap terang dan garis. Penelitian ini dilakukan di Vectorina Medan Community di mana permasalahan diangkat berdasarkan karya vector art yang ada di komunitas. Vector art merupakan salah satu karya grafis komputer di mana kary a dibuat dengan Software berbas is Vector. Dari penelitian yang sudah dilaksanakan maka bisa disimpulkan karakteristik karya vector art Vectorina Medan Community sangat kuat.
\end{abstract}

Kata Kunci: vector art, karakteristik, elemen visual.

\begin{abstract}
This study aims to determine the characteristik of visual elementsconsiting of lines, colors and light dark on the work vector art in Vectorina Medan Community 2019. As for the population contained in this study as many 100 vector art works in Vectorin Medan Community so the sample determined in this study consisted of 15 words using a purposive sampling technique. This study uses a qualitative descriptive method to determine and illustrate the streng th of the characteristics of vector art in the Vectorina Community in Medan, which is sampled based on the characteristics of lines, colors and light darkness. The results showed that the strength of visual elements based on characteristics came from the depiction and determination of goodvisual elements such as placement of colors, dark light and lines. This research was conducted at the Vectorina Community in Medan where problems arise based on vector art in the community. Vector art is one of the computer graphic works in which the work is made with Vector-based Software. From the research that has been done, it can be concluded that the characteristics of vectorina Medan Community vector art are very strong.
\end{abstract}

Keywords: vector art, characteristics, visualelements.

\section{PENDAHULUAN}

Pada zaman yang serba digital ini sebagian orang telah mengenal desain grafis sebagai salah satu karya seni rupa. Sebagian yang lain ternyata masih ada yang belum mengenal atau bahkan tidak dapat membuat karya grafis yang baik. Secara teknik desain grafis terdapat 2 teknik yaitu digital dan non digital teknik digital pada umunya menggunakan media komputer yang sering disebut grafis komputer ada dua jenis, yaitu vektor dan restar atau bitmap. Karya vektor berbeda dengan kaya bitmap. Karya berbasis vektor pada umumnya jika diperbesar tidak akan pecah dan kapasitas yang dipakai sedikit berbedadengan bitmap jika diperbesar akan pecah dan kapasitas yang dipakai bes ar. Pada s aat ini karya yang seperti itu sudah sangat populer sehingga banyak grafikus berkarya dengan model lalu membuatnya sebagai karya vector. Salah satu kary a vector adalah karya vector art suatu karya yang dibuat dengan aplikasi bebasis vector dengan medium, laptop, komputer, handphone dan sebagainya dimana objeknya adalah suatu tiruan benda, orang, tumbuhan, binatang, pemandangan alam. Karya ini 


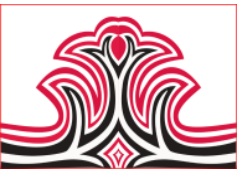

merupakan perpaduan dari garis (line), gelap terang dan warna yang dikomposisikan dengan tujuan menciptakan kemiripan pada objek gambar yang dijadikan sebagai model dan setiap karyanya pasti akan memiliki karakter.

Dalam karya ini, metode dan karakteristik yang didapat dari unsur-unsur visual sangatlah penting. Karena karakteritik yang dihasilkan oleh unsur visual yaitu gairis warna dan gelap dapat mempengaruhi seuatu kreatifitas seorang grafis kus terutama vectoris dalam berkarya dan menjadi suatu karakteritik pada karya tersebut.

Berdasarkan observasi atau pengamatan peneliti di Vectorina Medan Community, dan juga diperkuat dengan wawancara ketua komunitas tersebut, menunjukkan dari seluruh anggota Vectorina Medan Community, masih banyak yang belum memahami unsur-unsur visual.

Berdasarka observasi atau pengamatan peneliti di SMP Muhamamdiyah 7 Medan, dan juga diperkuat dengan wawancara guru bidang studi Seni Budaya di SMP Muhammadiyah 7 Medan, menunjukkan dari seluruh siswa kelas VIII, masih kurangnya pengetahuan anggota Vcetorina Medan Community tentang unsur-unsur visual masih kurang. Hal ini dikarenakan kurang memperhatikan penggunaan garis warna dan gelap terang pada pembuatan vector art.

\section{KAJIAN TEORI}

\section{Analisis}

Menurut Yusuf dalam buku Metode Penelitian Kuantatif, Kualitatif \& Penelitian Gabungan (2018:255) menjelaskan "Analisis merupakan salah satu langkah dalam kegiatan penelitian yang sangat menentukan ketepatan dan kesahihan hasil penelitian

\section{Bitmap dan Vektor}

Menurut Glitskha dalambuku Vector Basic Training (2011:22) menjelaskan "bitmap dan vektor berbeda, bitmap merupakan sebuah grafis komputer yang jika diperbesarakan pecah dan kapasitas yang digunakan sangat besar lain halya dengan vektor hanya membutuhkan kapasitas sedikit namun jika diperbes ar tidak akan pecah".

Berikut adalah aplikasi berbasis bitmap adobe Photoshop, CorelPaint Shop Pr, Corel Photo-Paint, GIMP dan vektor Adobe Illustrator, Corel Dra, Adobe Indesign, Inkscape.
Gorga : Jurnal Seni Rupa

Volume 09 Nomor 01 Januari-Juni 2020 p-ISSN: 2301-5942 | e-ISSN: 2580-2380

\section{Vector Art}

Menurut Glitskha dalambuku Vector Basic Training (2011:22) menjelaskan "gambar vektor terdiri dari jalur linier yang membuat gambar dan menyimpang informasi tentang titik-titik gambar".

\section{Prinsip-prinsip Desain pada Vector art}

Menurut Kusrianto (2007:23) dalam buku yang berjudul Pengantar Desain Komunikasi Visual menyatakan bahwa dalam suatu desain diperlakukannya suatu susunan atau komposisi yng harmonis dan dapat diperoleh dengan mengikuti prinsip-prinsip, berikut adalah prins ip-prinsip desain pad vector art, Kesatuan, Keseimbangan, Irama, Kontras, Fokus, Proporsi.

\section{Uns ur-unsur visual pada Vector art}

Menurut Anggraini \& Nathalia (2018:32 ) Unsurunsur visual terdiri dari garis, bentuk, tekstur, gelap terang, ukura, warna .

\section{Tinjauan Karakteristik/ Karakter pada Vector Art}

Pengertian Karakteristiktik yaitu mempunyai karakteris tiktik ses uai perawakan tertentu. Sedangkan menurut Kamus Oxford (2015:239) karakter adalah : all the quality and faetures thatmake a person, groups of people, and places different from other. "semua kualitas dan fituryang membuat seseorang, kelompok dan tempat berbeda dari yang lain".

Dalam hal ini, karakteris tiktik yang dimaksud adalah karakteristiktik vector art ditinjau garis, warna, dan gelap terang. Setiap karya seni rupa pada hakikatnya akan memperlihatkan karakteristiktik tersendiri, seperti halnya garis, warna dan gelap terang. Garis mempunyai peranan besar dalam memberikan kesan visual terhadap sebuah karya seni.

Beberapa karakteristiktikgaris pada vector art adalah garis (line art) yang ditarik secara ekspres if, spontan, tidak kaku dan menimbulkan kesan dinamis, menampilkan irama gerakdan arah pada keseluruhan gambar, adanya variasi kesan tebal tipis pada objek, memiliki salah satu garis lurus, lengkung, kontur, batas, outline, geometris dan organis.

Menurut para ahli, kepribadian dan tingkah laku seseorang dihubungkan dengan nilai simbolis warna. Dalam karya vector art, ada beberapa karakteristiktik warnaadalah menggunakan macam-macam warna sesuai dengan keinginan dan warna sebagai simbol ekspresi mereka, menggunakan salah satu shading warna selaras dan kontras, menggunakan salah satu 
warna panas dan dingin, menggunakan shading wama yang halus dan kasar.

\section{Garis}

\section{1). Pengertian Garis}

Menurut Kusrianto dalam buku Pengantar Desain Komunikasi Visual (2007:30) mengatakan : "Garis dianggap sebagai unsur vsual yang banyak berpengaruh terhadap pembentuka suatu objek sehing ga garis, selainy a dikenal sebagai gores an atau coretan, juga menjadi batas limit suatu bidang ataua warna.

\section{2). Jenis-Jenis Garis}

Menurut Anggraini dan Natalia alam buku Desain Komunikasi Visual (2018:32) mengatakan bahwa garis terdiri dari tiga jenis, yaitu, garis lurus, garis lengkung, garis majemuk.

\section{Warna}

\section{1). Teori Warna}

Menurut Nugroho (2011:13) dalam buku Pengenalan Teori Warna mengatakan "Warna adalah salah satu inspirasi paling berharga yang paling mudah didapati, sedangkan pengertian warna itu sendiri adalah s pektrum tertentu y ang terdapat di dalamsuatu cahaya sempurna (berwarna putih) yaitu, Teori Is aac Newton, Teori Johan Wolfgang Von Geothe, Teori Wilhelm Ostwald, Teori Albert, Miscellaneous. Warna merupakan bagian dari unsur-unsur yang ada dalam dunia Seni Rupa, dimana Unsur-unsur Seni Rupa meliputi, garis, raut, warna, gelap terang, tekstur, dan ruang (Sunaryo dalam Siregar, 2020: 96).

\section{Gelap Terang}

Anggraini \& Nathalia dalam bukunya yang berjudul Desain Komunikasi Visual (2018:35) mengatakan "Kontras merupakan warna yang berlawanan antara satu dengan lainnya, terdapat perbedaan baik warna atau titik fokus. Apabila tidak berwarna, dapat pula berupa perbedaan antara gelap dan terang. Gelap terang atau kontras ini dapat digunakan dalam des ain sebagai salah satu cara untuk menonjolkan pesan atau informasi yang dapat juga menambah kes an dramatis . Dengan mengatur komposisi gelap terang s atu desain, akan membantu nilai keterbacaan, fokus dan titik berat suatu desain".

\section{Vectorina Medan Community}

Vectorina Medan terbentuk pada tanggal 8 Januari 2017 oleh sekumpulan pemuda-pemuda yang sedang menuntut ilmu di salah satu Universitas Swasta di Medan. Pemilihan nama Vectorina Medan Community, di mana Vectorina adalah menandakan
Gorga : Jurnal Seni Rupa

Volume 09 Nomor 01 Januari-Juni 2020

p-ISSN: 2301-5942 | e-ISSN: 2580-2380

bahwa Komunitas ini khusus untuk karya vector dan vexel art, Sedangkan Ina berasal dari singkatan Indonesia, Medan adalah tempat Komunitas ters ebut dan Community adalah Komunitas yang diambil dari bahasa Inggris yang artinya kelompok. Sejak tahun 2017 Komunitas ini sudah aktif di Facebook dan Instagram bahkan sudah memiliki account official. Sekarang, Vectorina Medan memiliki 30 anggota yang di mana antaranya, 4 orang sebagai pengurus, 2 orang sebagai admin dan yang lainnya sebagai anggota. Vectorina Medan Community pernah mendapatkan kesempatan tayang di salah satu TV Swasta Medan dan di wawancarai serta diikuti kegiatannya. Dan pernah ikut bergabung diacara bergensi yaitu pada acara Sumpah Pemuda, yang pertemakan pemuda bergerak dan diiukti oleh 10 Kota secara serentak. Pernah bekerja sama dengan Museum Perkebunan Indonesia bersama komik Digidoy, WPAP Medan, dan banyak lagi. Vectorina Medan juga sudah 2 kali mengadakan pameran di Sekolah SMK TIK DARUSSALAM, pernah bekerja s ama dengan komik Digi Doy, menjadi salah satu Media Patner di Fakultas Bahasa dan Seni, Universitas Negeri Medan.

\section{METODE PENELITIAN}

Penelitian ini dilaksanakan di Jalan Mustafa No. 4636, Glugur Darat I, kec Medan Timur, Kota Medan, Sumatera Utara, 20238. Alamat ini merupakan tempat berkumpulan Vectorina Medan Community. Metode yang digunakan dalam penelitian ini adalah menggunakan metode kualitatif. Menurut Sugiyono dalam buku Statistika untuk Penelitian (2016:15) mengatakan "Metode kualitatif adalah metode penelitian yang berlandaskan pada filsafat postpositivisme digunakan untuk meneliti pada kondisi objek yang alamiah, (sebagai lawannya adalah eksperimen) di mana peneliti adalah sebagai in strumen kunci, pengambilan sampel sumber data dilakukan secara purposive dan snowbaal, teknik pengumpulan dengan trianggulasi (gabungan), analisis data bers ifat induktif/kualitatif lebih menekankan makna dari dari pada generalisasi. 


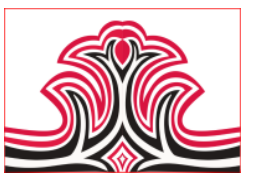

HASIL DAN PEMBAHASAN

\section{Hasil}

\section{1). Karya 1}

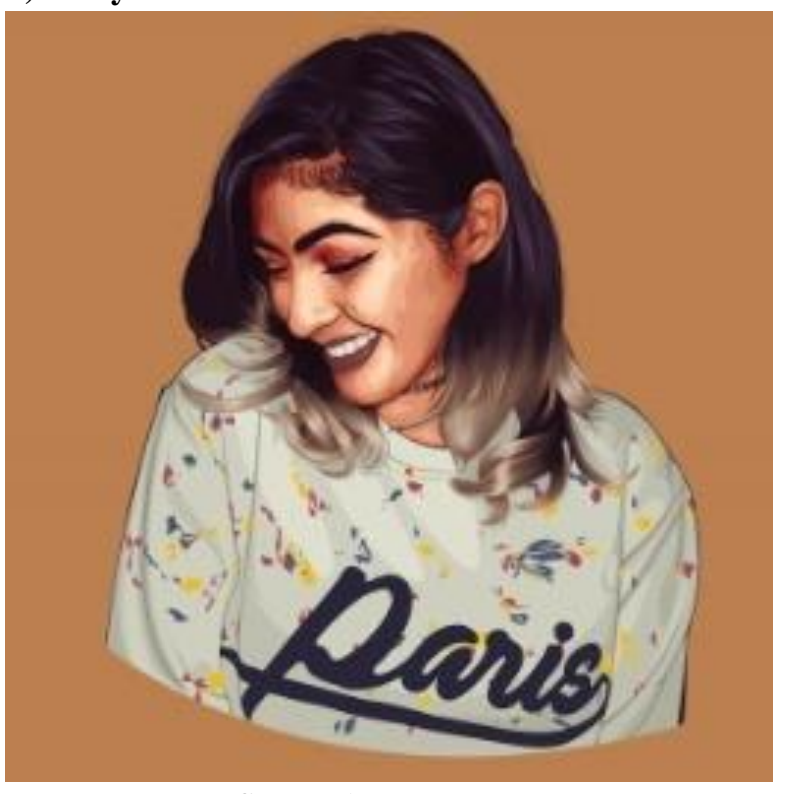

Gambar 1. Karya Aswiwir (Sumber: Lulu Riskiah, 2020)

Berdasarkan analisis data yang telah dipaparkan di atas, maka dapat ditarik kesimpulan interpretasi data atau penafiran data pada karya Aswwir, Karakteristiktik garis diungkapkan dengan garis yang spontan, dan organis. Kelancaran tarikan daris terkontrol dan jelas. Karakteristiktik warna secara keseluruhan warna yang paling menonjol adalah warna skintoon kulit. Karakteristiktik gelap terang terlihat jelas, memiliki dimesi, volume, dinamika dan irama. Dalam proses karya Aswiwir menggunakan aplikasi Adobe Ilustrator, dalam proses pembuatan menggunakan pentool. Proses metode penerapan dengan melakukan cara dan tahapan menjiblak langsung gambar yang ada dilayar laptop. Lalu berfokus pada kunci $\mathrm{T}$, kunci $\mathrm{T}$ bias a sering dibilang dalam ilmu seni rupa adalah area mata, hidung dan mulut. Membuat kunci T secara detail dengan garis, warna dan gelap terang, Kemudian membuat bagian pada skintoon wajah dengan warna dan gelap terang yang jelas sehingga gambar terlihat mendetail. Setelah itu mulai mentracing rambut dengan warna dasar lalu ke daerah gelap dan terang. Kemudian baju dengan cara yang sama lalu background.

\section{Karya 2}

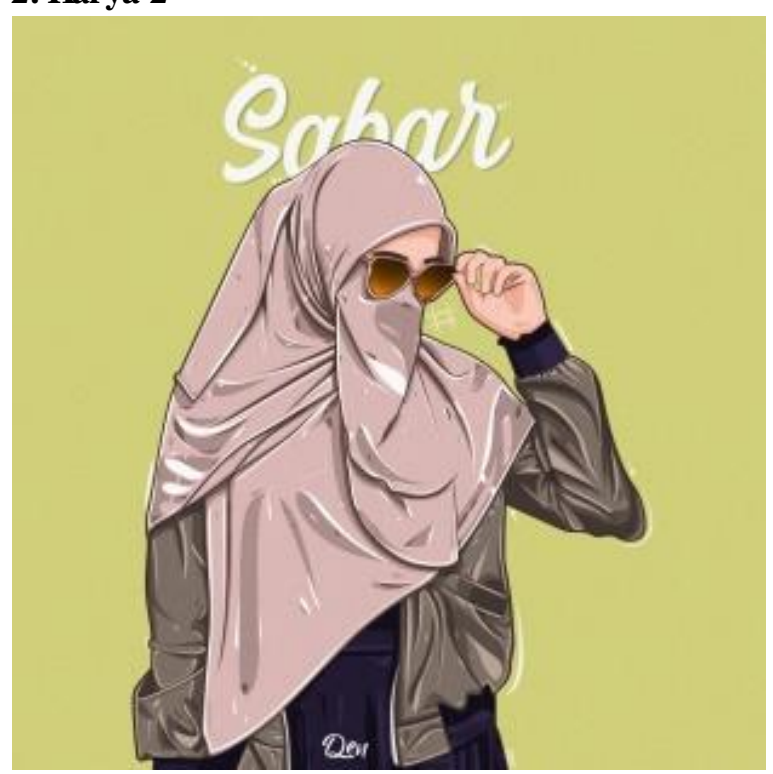

Gambar 2. Karya Dendi (Sumber: Lulu Riskiah, 2020)

Berdasarkan analisis data yang telah dipaparkan di atas, maka dapat ditarik kesimpulan interpretasi data atau penafsiran data pada karya Dendi, karakteristik gari diungkapkan dengan garis organis, outline dan kontur. Karakterstik warna Secara keseluruhan menggunakan warna yang kontras dan enak dipandang mata, meskipun hanya menggunakan warna yang sederhana. Karakteristik gelap terang W alaupun hanya menggunkaan warna yang sedmerahana warna, gelap terang di karya ini sangat terlihat jelas. Dalam karya Dendi menggunakan Adobe Ilustratorsebagai apalikasinya. Metode penerapan dengan melakukan proses dan tahapan menjiblak langsung gambar yang ada di layar laptop dengan bantuain pentool. Lalu pertama membuat line art dan outline pada objek. Lalu berfokus pada pewarnaan dan gelap terang wajah, tangan. Lalu membuat memulain shading dengan pada jilbab, cadat baju, jaket rok, dan kacamata. Kemudian memperindannya dengan membuat background berwarna soft dan memberi sebuah tulisan "sabar" agar menambahkan kesan estetis. 


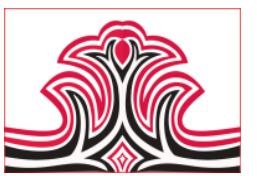

3). Karya 3

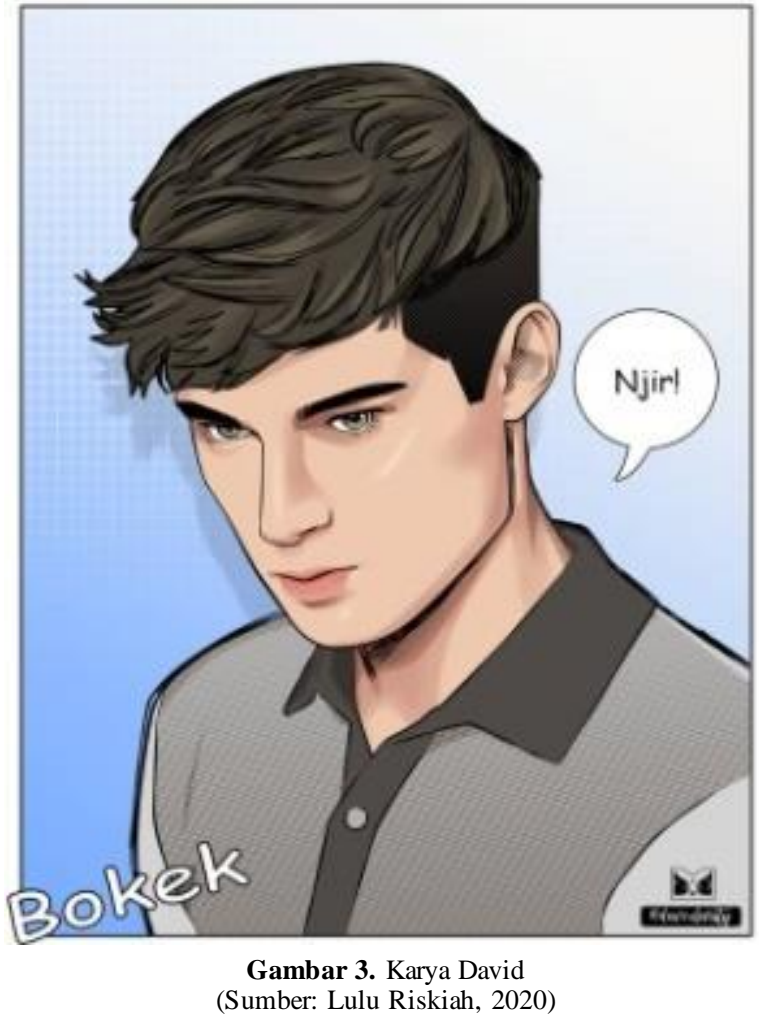

Berdasarkan analisis data yang telah dipaparkan di atas, maka dapat ditarik kesimpulan interpretasi data atau penafsiran data pada karya David, karakteristik garis dapat menuangkan ide melalui bentuk yang diciptakan oleh garis yang unik dan khas. Dan dimanfaatkan menjadi sebuah arsiran, jadi menambahkan kes an estetis yang khas. Karakteristik warna pada karya ini kontras, perpaduan warna yang terang, cerah, dan sederhana membuat karya enak dilihat walapun karyanya simpel. Dan karakteristik gelap terang Patra terang dan patra gelap dengan komposisi yang simpel namu tetap menarik dan menimbulkan dinamika dan dimensi yang indah. Proses pembuatan karya David menggunakan Adobe Ilustrator, metode penerapan dengan melakukan proses dan tahapan menjiblak langsung pada gambar yang ada dilayar laptop dengan menggunakan pentool. Lalu pertama membuat line art pada objek. Berfokus pada kunci $\mathrm{T}$, kunci $\mathrm{T}$ bias a sering dibilang dalam ilmu seni rupa adalah area mata, hidung dan mulut. Dan membuat semua bagia dengan satu persatu secara detail. Dan davis menambahkan efek gradasi pada suatu warna dengan bantuan brush.

\section{Pembahasan}

Dalam penelitian ini, peneliti menganalisis gambar poster karya anggota Vectorina Medan Community yang ditinjau garis, warna dan gelap terang. Karya yang ditelitiberjumlah sebanyak 3 karya, y ang dinilai oleh Bapak dosen Pendidikan Seni Rupa Universitas
Gorga : Jurnal Seni Rupa

Volume 09 Nomor 01 Januari-Juni 2020

p-ISSN: $2301-5942$ | e-ISSN: 2580-2380

Negeri Medan sebagai penilai Idan II seniman.. Adek Cerah Kurnia Aziz, S.Pd.,M.Pd, (Penilai I), Leo Sugali (Penilai II). Hasil penelitian tersebut dinilai dalam bentuk tabulasi data berupa in strumen penilaian lalu dianalisis dan dideskripsikan. Kemudian hasil penelitian dalam bentuk tabulasi tersebut menunjukkan hasil karya tersebut termasuk dalam kategori baik.

\section{KESIMPULAN DAN SARAN \\ 1.Kesimpulan}

Berdasarkan rumusan masalah, landasan teori, pembahasan dan temuan hasil penelitian, maka dapat disimpulkan sebagai berikut, Karakteristiktik karya vector art pada VM dengan kualitas sangat kuat. Temuan ini hasil dari 3 karya yang dihasilkan dari 3 orang. garis, warna dan gelap terang pada VM memiliki 3 karya berkarakter dan unik ditemukan yang dibuat 3 orang ternyata menghasilkan karakteristiktik yang berbeda pula kepribadian dalam karakteristiktik masing-masing anggota dalam pembawaannya di setiap pembuatan karya dan menggambarkan emosi serta kepribadian yang mereka rasakan. Pada penerapan metode pada VM, ternyata ada beberapa cara, metode, tahapan dan langkah-langkah yang berbeda dalam pembuatan vectorart. Dan dari 3 orang tersebut meskipun pada awalnya meniru gaya dan cara membuat tutorial dari seseorang, pasti akan adasedikit banyakny a perbedaan penerapan metode pada pembuatan karyanya. Dari penelitian ini ternyata alat, emosi juga mampu membuat perbedaan pada penerapan metode. Dari penelitian ini, ternyata alat, emosi juga mampu membuat perbedaan pada penerapan metode.

\section{Saran}

Berdasarkan hasil penelitian, analisis dan simpulan penelitian, maka penelitian menyarankan sebagai berikut, bagi para anggota Vectorina Medan Community, karakteristik masing-masing anggota bisa lebih digali lagi, untuk membangun ketertarikan khalayak luas untuk membangun jati diri. Bagi para anggota Vectorina Medan Community, Dalam metode penerapan unsur visual dengan cara dan tahapannya sendiri, sesuai dengan pengetahuan dan kenyaman mereka sendrir. Jang an terpaku pada satu alat, bahan dan software karena harus menguasain segala macam alat, dan bahan. Bagi dunia pendidikan seni rupa diharapkan dapa mempertibmakngka pentingnya mengkaji dan melakukan riset lebih mendalam halahal yang berkaitan deng an kekuatan dari karakteristik unsur visaul dan non visual vector art. Bagi peneliti selanjutnya, diharapkan dapat enjadi penelitian ini menjadi referensidan dikembangkan pada penelitian 


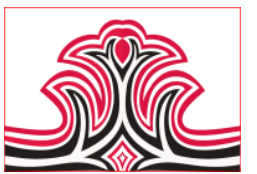

selanjutnya yang lebih mendalam terkait tentang vector art.

\section{DAFTAR RUJUKAN}

Anggraini S, Lian dan Kirana Nathalia. (2018).

Desain Komunikasi Visula. Bandung: Nuansa Cendekia.

Kusrianto, Adi. (2007). Pengantar Desain Komunikasi Visual. Yogyakarta :CV Offset

Nugroho, Eko. (2008). Pengenalan Teori Warna.

Yogyakarta:C.V Andi Offset.

Glits chka, Von. 2011. Vector Basic Training.

Amerika: The United States Of Amerika.

Siregar, N. H., Azis, A. C. K., Mesra, M., \& Mirwa, T.

(2020). Analis is Gambar Bentuk Bunga

Anggrek dengan Teknik Pointilis Berwarna di SMP Al-Fity an School Medan. Gorga: Jurnal Seni Rupa, 9(1), 94-99.

Sugiyono. (2016). Metode Penelitian Kuantitatif,

Kualitatif, dan R\&D. Bandung: Alfabeta.

Yusuf, Muri. (2018). Metode Penelitian Kuantitatif,

Kualitatif \& Penelitian Gabungan. Jakarta:

Kencana. 